\title{
Selection of in-situ Desulfurizers for Chicken Manure Biogas and Prediction of Dosage
}

\author{
Hao Jiang ${ }^{1}$, Teng Li ${ }^{1}$, Walter Stinner ${ }^{2}$, Hong Nie ${ }^{1}$, \\ Jiangtao Ding ${ }^{1}$, Hongjun Zhou ${ }^{1 *}$ \\ ${ }^{1}$ Institute of New Energy, State Key Laboratory of Heavy Oil Processing, Beijing Key Laboratory \\ of Biogas Upgrading Utilization, China University of Petroleum, Beijing 102249, China \\ ${ }^{2}$ Biochemical Conversion Department, Deutsches Biomasseforschungszentrum gGmbH (DBFZ), \\ Torgauer Straße 116, 04347 Leipzig, Germany
}

Received: 25 July 2016

Accepted: 30 September 2016

\begin{abstract}
The hydrogen sulfide $\left(\mathrm{H}_{2} \mathrm{~S}\right)$ in biogas is poisonous and corrosive, so it is usually removed in the early stage of biogas upgrading. Dosing iron compounds directly into the anaerobic fermenter is an in-situ method for rough desulphurization. But it is difficult to estimate the appropriate amount of iron compound to add and overdosing is usually inevitable. Five kinds of iron compounds $\left(\mathrm{FeCl}_{2}, \mathrm{FeCl}_{3}, \mathrm{Fe}(\mathrm{OH})_{3}, \mathrm{Fe}_{2} \mathrm{O}_{3}\right.$, and $\mathrm{FeSO}_{4}$ ) were applied as in-situ desulfurizers in chicken manure fermentation to reduce $\mathrm{H}_{2} \mathrm{~S}$ emissions. Biogas yield, $\mathrm{CH}_{4}$ concentration, and $\mathrm{H}_{2} \mathrm{~S}$ concentration were examined to evaluate the performance of these desulfurizers. Among these five desulfurizers, $\mathrm{FeCl}_{2}, \mathrm{FeCl}_{3}$, and $\mathrm{Fe}(\mathrm{OH})_{3}$ showed better performance; the desulfurization rates were all above $98.5 \%$ when the addition was $16 \mathrm{mmol} \mathrm{L}^{-1}$. In order to establish the prediction model of the required amount for in-situ desulfurizer, it is assumed that the dosage of desulfurizer could be simply divided into two parts: one part for consumption of released $\mathrm{H}_{2} \mathrm{~S}$, and the other part for guaranteeing a certain desulfurizing level. Under this assumption, the prediction formulas were fitted based on the bottle experiments and applied in a $5 \mathrm{~L}$ fermentation system. The required desulfurization levels $\left(\mathrm{H}_{2} \mathrm{~S}\right.$ concentration) when adding $\mathrm{FeCl}_{2}, \mathrm{FeCl}_{3}$, and $\mathrm{Fe}(\mathrm{OH})_{3}$ were set to 120,200 , and 100 ppmv, respectively. After adding the calculated dosage of the three in-situ desulfurizers, the actual $\mathrm{H}_{2} \mathrm{~S}$ concentrations were 163.0, 180.3, and 89.4 ppmv, respectively, which were relatively closed to the required desulfurization levels.
\end{abstract}

Keywords: biogas, desulfurizer, hydrogen sulfide, anaerobic fermentation, dosage

\section{Introduction}

Against the backdrop of less fossil fuel and more severe environmental pollution, energy recovery from organic

*e-mail: zhouhongjun@cup.edu.cn residues is becoming a more attractive proposition. Biogas, produced by microorganisms during anaerobic biomass fermentation, consists primarily of $\mathrm{CH}_{4}(40-75 \%)$ and $\mathrm{CO}_{2}(15-60 \%)$, as well as $\mathrm{H}_{2} \mathrm{~S}(0.005-2 \%)$ and other trace components [1]. After desulphurization and dehydration, biogas can be used to generate heat and electricity. After further upgrading process to increase the concentration 
of $\mathrm{CH}_{4}$ and reduce impurities, biogas can be transformed into biomethane and applied as a substitute of natural gas.

The $\mathrm{H}_{2} \mathrm{~S}$ in biogas is mainly related to the anaerobic degradation of S-containing organic material such as sulfolipid or amino acid, or formatted by sulfate reduction, where sulfate is used as the terminal electron acceptor [2]. The $\mathrm{H}_{2} \mathrm{~S}$ content depends on the type of organic substrates feeding for fermentation. The fermentation of manure or food waste shows typical $\mathrm{H}_{2} \mathrm{~S}$ concentrations in the range of 2,000-6,000 ppmv in biogas, while for anaerobic wastewater treatment in the paper industry, $\mathrm{H}_{2} \mathrm{~S}$ concentration can be measured at up to 30,000 ppmv [3].

$\mathrm{H}_{2} \mathrm{~S}$ can cause corrosion in pipelines and equipment, along with high toxicity for health and the environment. Therefore, it is usually removed in an early state of the biogas upgrading process. A variety of methods have been used for desulphurization, which can be classified as physical, chemical, and biological methods according to principle, or as in-situ and external according to process, or as rough and fine desulphurization according to purification level. The comparative overview of these methods is given elsewhere [1, 4-5]. The method or combination of methods for desulphurization can be determined based on the biogas composition and subsequent utilization.

Dosing iron compounds (especially iron salts) directly into the fermenter is an in-situ method for rough desulphurization. This desulphurization method has the advantages of simple operation, small investment, and good desulphurization rate. Five kinds of natural iron ores were used as in-situ desulfurizers during the anaerobic digestion of waste-activated sludge, and limonite showed high desulfurization efficiency [6]. Besides being used as $\mathrm{H}_{2} \mathrm{~S}$ control in anaerobic fermenters, iron compounds have been widely used for the abatement of sulfide-associated problems in sewer systems [7-8]. The reactions among iron and sulfide species in these aqueous phases are complex and have not yet been unequivocally ascertained and quantified [9]. Under the most common description, the main desulphurization interactions occurring in anaerobic fermenters are shown in Equations 1 and 2 [1, 9]. Fe (II) can remove sulfide by forming ferrous sulfide precipitation. Fe (III) can remove sulfide by oxidizing it to sulfur while being reduced to Fe (II), which can subsequently produce ferrous sulfide.

$$
\begin{gathered}
\mathrm{Fe}^{2+}+\mathrm{HS}^{-} \rightarrow \mathrm{FeS}+\mathrm{H}^{+} \\
2 \mathrm{Fe}^{3+}+\mathrm{HS}^{-} \rightarrow 2 \mathrm{Fe}^{2+}+\mathrm{S}+\mathrm{H}^{+}
\end{gathered}
$$

The achievable desulfurizing level of this method is about 100-150 ppmv [1], but it is difficult to estimate the appropriate adding amount of iron compound and the practical application relies heavily on empirical experience. For the assurance of desulphurization effect, overdosing is usually necessary, which not only increases operational cost, but also poses a potential pollution risk. In addition, too much iron compound could reduce the availability of necessary nutrients like phosphate and sulfur.
In this study, different iron compounds, including $\mathrm{FeCl}_{2}, \mathrm{FeCl}_{3}, \mathrm{Fe}(\mathrm{OH})_{3}, \mathrm{Fe}_{2} \mathrm{O}_{3}$, and $\mathrm{FeSO}_{4}$, were applied as in-situ desulfurizers in chicken manure (CM) fermentation to reduce the emission of $\mathrm{H}_{2} \mathrm{~S}$. The biogas yield, $\mathrm{CH}_{4}$ concentration, and $\mathrm{H}_{2} \mathrm{~S}$ concentration were examined to evaluate the performance of these desulfurizers. In order to establish the prediction model of the required amount for in-situ desulfurizer, it is assumed that the dosage of a desulfurizer could simply be divided into two parts, one part for consumption of released $\mathrm{H}_{2} \mathrm{~S}$ and the other part for guaranteeing a certain desulfurizing level. Under this assumption, the prediction formulas were fitted and applied successfully in a larger fermentation system.

\section{Materials and Methods}

\section{Substrates and Inoculum}

Two batches of fresh CM were successively collected from a chicken farm (DQY Ecological Farm, Beijing, China), labeled CM1 and CM2, respectively. The total solids (TS) and volatile solids (VS) were determined to be $29.1 \%$ (based on fresh mass) and $68.0 \%$ (based on TS) for CM1, and $30.7 \%$ and $35.1 \%$ for CM2. The digested effluent of the biogas plant feeding $\mathrm{CM}$ on the farm was used as inoculum. The TS of the inoculum was below $1 \%$, so the contribution of inoculum to solid content was ignored in calculation.

\section{Fermentation and in-situ Desulfurization}

The batch fermentation of $\mathrm{CM}$ and in-situ desulfurization were taken in two kinds of apparatuses: $50 \mathrm{~mL}$ bottles and $5 \mathrm{~L}$ fermenters (BIOTECH-5JG-2, Baoxing Bio-Engineering Equipment Company, Shanghai, China). For all fermentation, the inoculum took $35 \%$ of the loading volume, and the initial TS content was adjusted to $7.0 \%$ through mixing $\mathrm{CM}$, inoculum, and water. The bottles were loaded with $25 \mathrm{~mL}$ feed mixture and incubated at $37^{\circ} \mathrm{C}$ and $130 \mathrm{r} \mathrm{min}^{-1}$. Five kinds of iron compounds $\left(\mathrm{FeCl}_{2}, \mathrm{FeCl}_{3}, \mathrm{Fe}(\mathrm{OH})_{3}, \mathrm{Fe}_{2} \mathrm{O}_{3}\right.$ and $\left.\mathrm{FeSO}_{4}\right)$ were added into bottles as in-situ desulfurizers with the feedstock, respectively. For each iron compound, different initial concentrations based on the fermentation volume were applied, which were 0 (as a control), 2, 4, 8, 12, 16 , and $32 \mathrm{mmol} \mathrm{L}^{-1}$, respectively. In $5 \mathrm{~L}$ fermenters, the feeding volume was $3.5 \mathrm{~L}$. The temperature was kept at $37^{\circ} \mathrm{C}$ and the stirring rate was $100 \mathrm{r} \mathrm{min}^{-1}$. CM1 was the feedstock in bottles except that when $\mathrm{Fe}(\mathrm{OH})_{3}$ was applied as the desulfurizer, while CM2 was fed in $5 \mathrm{~L}$ fermenters as well as bottles adding $\mathrm{Fe}(\mathrm{OH})_{3}$.

\section{Prediction Model of Desulfurizer Dosage}

The dosage of desulfurizers was assumed to be divided into two parts: one for consumption of released $\mathrm{H}_{2} \mathrm{~S}$ and the other for guaranteeing a certain desulfurizing level. It was calculated by Equation 3: 


$$
m=m_{r}+x V
$$

...where $m$ is the dosage of desulfurizer; $m_{r}$ represents the amount of desulfurizer that reacted with reduced $\mathrm{H}_{2} \mathrm{~S}$, whereas the reduced $\mathrm{H}_{2} \mathrm{~S}$ can be calculated by subtracting the expected value of $\mathrm{H}_{2} \mathrm{~S}$ from the $\mathrm{H}_{2} \mathrm{~S}$ yield without desulfurizer added; $x$ represents the needed concentration of desulfurizer maintained in the liquid for achieving a specific $\mathrm{H}_{2} \mathrm{~S}$ value in biogas; and $V$ is the fermentation volume. The relationship between $\mathrm{H}_{2} \mathrm{~S}$ concentration in biogas and desulfurizer concentration in liquid $(x)$ can be obtained by fitting experimental data during the middle period of the $50 \mathrm{~mL}$ fermentation.

\section{Analytical Methods}

TS and VS were determined according to the standard methods [10]. For $50 \mathrm{~mL}$ bottles, $\mathrm{pH}$ was measured using a pH meter (PHSJ-4A, REX Instrument Company, Shanghai, China), and biogas yield was determined by $100 \mathrm{~mL}$ syringe. For $5 \mathrm{~L}$ fermenters, $\mathrm{pH}$ was recorded automatically, and biogas yield was determined by the gas-collecting method of draining saturated $\mathrm{NaHCO}_{3}$. The concentration of $\mathrm{CH}_{4}$ was analyzed by gas chromatography (GC) with a thermal conductivity detector (TCD) (Model GC-2000III, Shanghai Institute of Computing Technology, China) and a packed TDX-01 column using $\mathrm{H}_{2}$ as the carrier gas. The temperatures of the injector, column, and TCD were 150,120 , and $250^{\circ} \mathrm{C}$, respectively. The concentration of $\mathrm{H}_{2} \mathrm{~S}$ was analyzed by GC (Agilent 7890A, Agilent Technologies, USA) with a sulfur chemiluminescence detector (SCD) using a capillary column GS-GASPRO $(60 \mathrm{~m} \times 0.32 \mathrm{~mm})$, and the carrier gas was He. The initial temperature of the column was $60^{\circ} \mathrm{C}$ for three minutes. Then the column was heated to $200^{\circ} \mathrm{C}$ at a rate of $10^{\circ} \mathrm{C}$ $\mathrm{min}^{-1}$, and finally kept for 15 minutes. The temperatures of the injector, $\mathrm{SCD}$, and burner were 250,250 , and $800^{\circ} \mathrm{C}$, respectively.

\section{Results and Discussion}

\section{Selection of in-situ Desulfurizers}

Five iron compounds $\left(\mathrm{FeCl}_{2}, \mathrm{FeCl}_{3}, \mathrm{Fe}(\mathrm{OH})_{3}\right.$, $\mathrm{Fe}_{2} \mathrm{O}_{3}$ and $\mathrm{FeSO}_{4}$ ) were applied as in-situ desulfurizers with different concentrations in $50 \mathrm{~mL}$ bottles. The characteristics of biogas production were shown in Fig. 1. Compared with the controls, the biogas yield and $\mathrm{CH}_{4}$ concentration of the $\mathrm{CM}$ fermentation with desulfurizers showed no obvious differences, indicating that adding iron compounds did not cause significant inhibition or promotion to the biogas production. Iron is an essential trace element that is required by methanogens and other microorganisms during fermentation for electron transport and function of certain enzymes [11]. The optimum iron concentration was reported to range from 0.28 to $50.4 \mathrm{~g} \mathrm{~m}^{-3}$ [12]. Some studies have proven that adding iron could provide more biogas production and $\mathrm{CH}_{4}$ content, especially in the mono-fermentation of agricultural crops, which suffers from a lack of trace elements easily [13-14]. But there are seldom reports about the deficiency of trace elements in CM fermentation, and in fact feeding with animal excrement can generally satisfy the demand for micronutrients [11]. Therefore, adding iron compounds had no significant influence on biogas production in this study. Zhou et al. found that adding limonite had different impacts on biogas production with different initial concentrations of sulfate, which might be due to the changes of microbial quantity and activity under different conditions [6].

The desulfurization rates of different desulfurizers at different concentrations are listed in Table 1. Combined with the $\mathrm{H}_{2} \mathrm{~S}$ concentration changes in Fig. 1, it clear that the $\mathrm{H}_{2} \mathrm{~S}$ content decreased obviously after adding desulfurizers. For each kind of iron compound, the more amounts added, the less $\mathrm{H}_{2} \mathrm{~S}$ was obtained. Among these five in-situ desulfurizers, $\mathrm{FeCl}_{2}, \mathrm{FeCl}_{3}$ and $\mathrm{Fe}(\mathrm{OH})_{3}$ showed better performance; the desulfurization rates were all above $98.5 \%$ when the addition was $16 \mathrm{mmol} \mathrm{L}^{-1}$. Considering avoiding the introduction of other potentially polluting ions, $\mathrm{Fe}(\mathrm{OH})_{3}$ was more environmentally friendly. Compared with the three desulfurizers mentioned above, the desulfurization efficiency of $\mathrm{Fe}_{2} \mathrm{O}_{3}$ was much lower, and when the addition was $16 \mathrm{mmol} \mathrm{L}^{-1}$, the desulfurization rate was only $90.5 \%$. Due to its insolubility in water, $\mathrm{Fe}_{2} \mathrm{O}_{3}$ could not fully contact and react with $\mathrm{H}_{2} \mathrm{~S}$. So it is not a good choice as an in-situ desulfurizer. When $\mathrm{FeSO}_{4}$ was applied, the desulfurization effect seemed normal in the early stage of fermentation, but later the $\mathrm{H}_{2} \mathrm{~S}$ concentration increased sharply - far higher than that of control (up to $9,000 \mathrm{ppmv}$ ). This indicated that the added $\mathrm{SO}_{4}^{2-}$ got involved in the microbial reaction process, employed by sulfate-reducing bacteria as an electron acceptor to generate $\mathrm{H}_{2} \mathrm{~S}[6,15]$. Therefore, $\mathrm{FeSO}_{4}$ was not suitable for in-situ desulfurization use. In the following model calculation and experiments, the three desulfurizers with good performance $\left(\mathrm{FeCl}_{2}, \mathrm{FeCl}_{3}\right.$ and $\left.\mathrm{Fe}(\mathrm{OH})_{3}\right)$ were applied.

\section{Prediction Model of Desulfurizer Dosage}

To determine the dosage of desulfurizer is key for the insitu desulfurization process. But until now, there has been no public report about how to determine the desulfurizer addition. We supposed that the $\mathrm{H}_{2} \mathrm{~S}$ concentration was associated with the concentration of the desulfurizer in fermentation liquid. Through the experiments in 50 $\mathrm{mL}$ bottles, the fitted curve between the desulfurizer concentration in liquid and the $\mathrm{H}_{2} \mathrm{~S}$ concentration in biogas was acquired (Fig. 2). The fitting formula was shown as Equation 4 and the values of $R^{2}$ were all above 0.999 .

$$
y=\left(a+b x^{c}\right)^{-1}
$$

...where $x$ represents the desulfurizer content in the liquid and $y$ represents the $\mathrm{H}_{2} \mathrm{~S}$ content in biogas. For $\mathrm{FeCl}_{2}$, the values of $a, b$, and $c$ were $-5.09 \times 10^{-4}, 0.0016$, and 
a) $\mathrm{FeCl}_{2}$
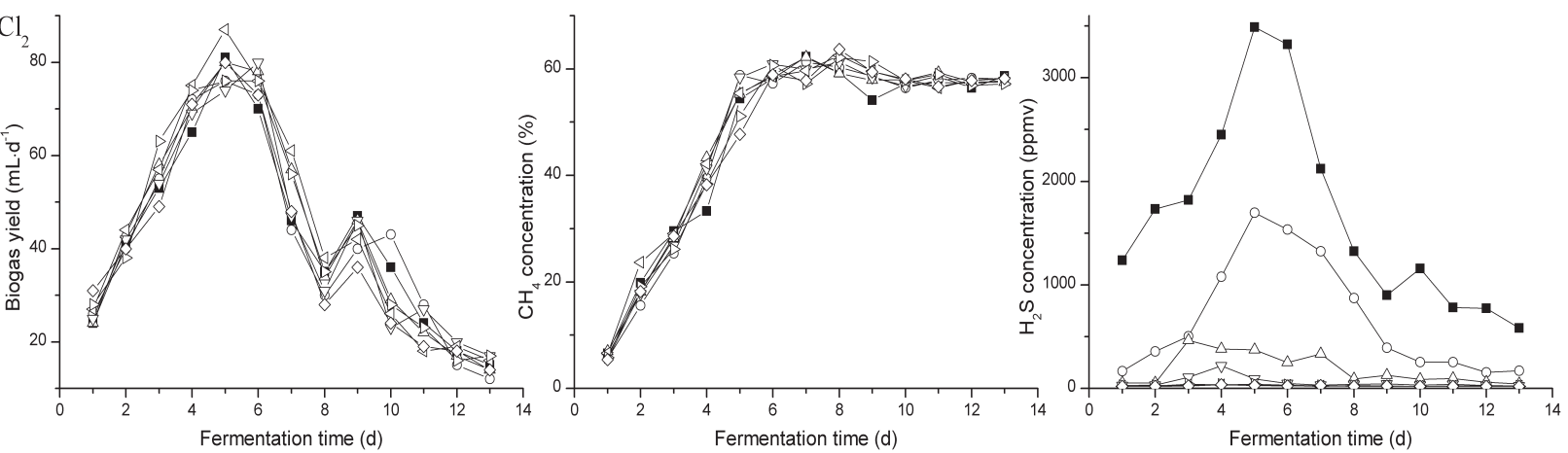

b) $\mathrm{FeCl}_{3}$
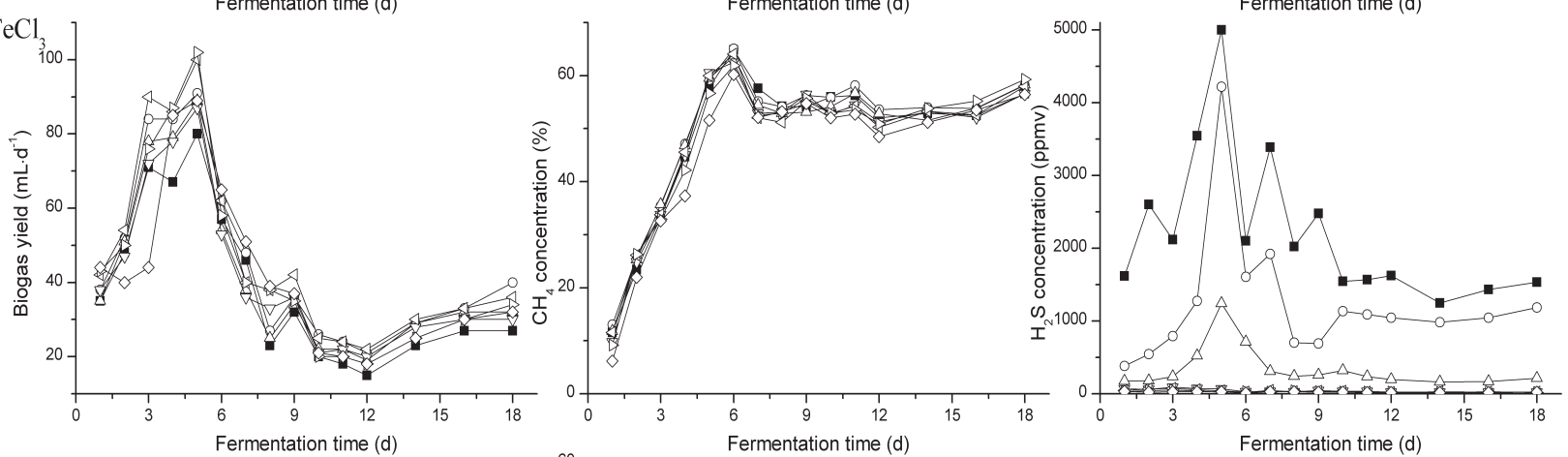

c) $\mathrm{Fe}(\mathrm{OH})_{3}$
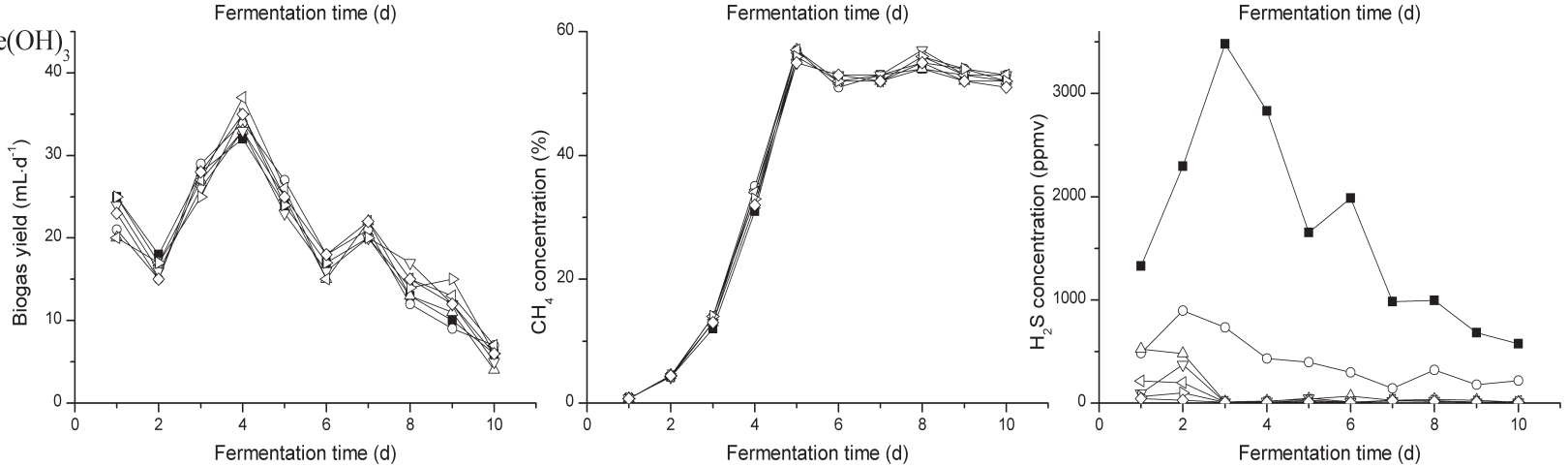

d) $\mathrm{Fe}_{2} \mathrm{O}_{3}$
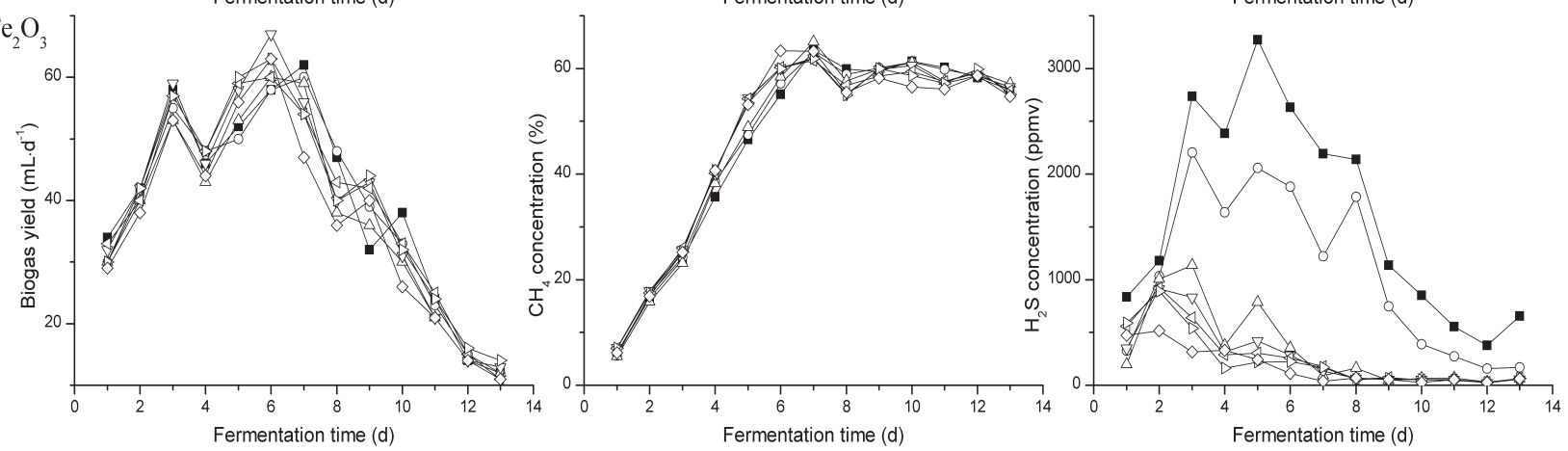

e) $\mathrm{FeSO}_{4}$
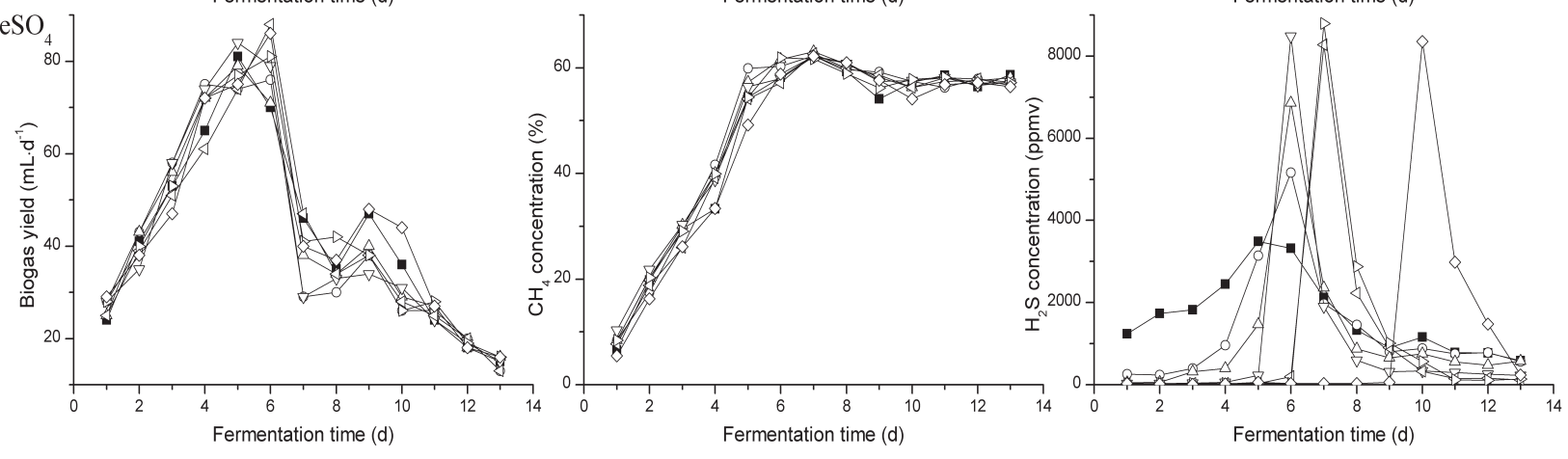

- control (0 mM); -2 mM; $\triangle 4 \mathrm{mM} ;-\nabla-8 \mathrm{mM} ; \triangleleft 12 \mathrm{mM} ;-16 \mathrm{mM} ;->32 \mathrm{mM}$

Fig. 1. Biogas yield, $\mathrm{CH}_{4}$ concentration, and $\mathrm{H}_{2} \mathrm{~S}$ concentration when using a) $\mathrm{FeCl}_{2}$, b) $\left.\mathrm{FeCl}_{3}, \mathrm{c}\right) \mathrm{Fe}(\mathrm{OH})_{3}$, d) $\mathrm{Fe}_{2} \mathrm{O}_{3}$, and e) $\mathrm{FeSO}_{4}$ as in-situ desulfurizers with different concentrations in $50 \mathrm{~mL}$ bottles. 
Table 1. Desulfurization rates of different desulfurizers at different concentrations.

\begin{tabular}{|c|c|c|c|c|c|}
\hline \multirow{2}{*}{$\begin{array}{c}\text { Concentration } \\
\text { of desulfurizer } \\
\left(\mathrm{mmol} \mathrm{L}^{-1}\right)\end{array}$} & \multicolumn{5}{|c|}{ Desulphurization rate (\%) } \\
\cline { 2 - 6 } & $\mathrm{FeCl}_{2}$ & $\mathrm{FeCl}_{3}$ & $\mathrm{Fe}(\mathrm{OH})_{3}$ & $\mathrm{Fe}_{2} \mathrm{O}_{3}$ & $\mathrm{FeSO}_{4}$ \\
\hline 2 & 57.3 & 34.5 & 77.4 & 32.5 & 18.1 \\
\hline 4 & 87.7 & 81.9 & 93.9 & 79.7 & 25.2 \\
\hline 8 & 96.4 & 97.9 & 97.0 & 82.7 & 29.0 \\
\hline 12 & 98.6 & 98.1 & 97.4 & 84.2 & 52.6 \\
\hline 16 & 98.5 & 98.6 & 98.7 & 86.1 & 51.6 \\
\hline 32 & 98.9 & 99.0 & 99.1 & 90.5 & 56.7 \\
\hline
\end{tabular}

1.171, respectively; for $\mathrm{FeCl}_{3}$ the values of $a, b$, and $c$ were $2.295 \times 10^{-4}, 1.504 \times 10^{-4}$, and 2.561 , respectively; for $\mathrm{Fe}(\mathrm{OH})_{3}$, the values of $a, b$, and $c$ were $0.1572,-0.1777$, and -0.2731 , respectively. In fact, the form of Equation 4 is not unchangeable and could be replaced by other forms, as long as it reflects the relationship between $x$ and $y$ in the concentration range of desulfurizer.

For example, when $\mathrm{FeCl}_{2}$ was used as the in-situ desulfurizer, if the required $\mathrm{H}_{2} \mathrm{~S}$ content in biogas was 200-300 ppmv, according to Equation 4, the $\mathrm{FeCl}_{2}$ concentration in liquid should maintain around 2.11-2.87 mmol L-1 if the required $\mathrm{H}_{2} \mathrm{~S}$ content in biogas was 50 ppmv, the $\mathrm{FeCl}_{2}$ concentration in liquid should be $8.83 \mathrm{mmol} \mathrm{L}^{-1}$. It also can be seen from Fig. 2 that with the increase of desulfurization level, much more addition of desulfurizer would be needed, and the $\mathrm{H}_{2} \mathrm{~S}$ content in the biogas could not be reduced unboundedly.
In practical application, it is necessary to consider the trade-off between desulfurization level and desulfurizer cost. If necessary, this in-situ desulfurization method can combine with a fine desulfurization process to obtain a higher desulfurization rate economically.

Through Equations 3 and 4, for a certain required $\mathrm{H}_{2} \mathrm{~S}$ concentration, the additional quantity of in-situ desulfurizer can be calculated.

\section{Application of Prediction Model in $5 \mathrm{~L}$ Fermentation}

The prediction model was applied in $5 \mathrm{~L}$ fermenters. Firstly, the control fermentation without desulfurizer was performed, and the amount of $\mathrm{H}_{2} \mathrm{~S}$ was recorded. In this experiment, the $\mathrm{H}_{2} \mathrm{~S}$ concentrations in biogas were assumed to be demanded below 120,200 , and $100 \mathrm{ppmv}$ when $\mathrm{FeCl}_{2}$, $\mathrm{FeCl}_{3}$, and $\mathrm{Fe}(\mathrm{OH})_{3}$ were added as in-situ desulfurizers, respectively. Then $m_{r}$ can be calculated, and $x$ can be obtained through Equation 4. Dosage $m$ was determined by Equation 3. Table 2 lists the calculated dosage of the three in-situ desulfurizers, as well as the actual desulfurization efficiency after adding them. Furthermore, the changes of biogas yield, $\mathrm{CH}_{4}$ concentration, and $\mathrm{pH}$ are shown in Fig. 3; the changes of $\mathrm{H}_{2} \mathrm{~S}$ concentration are shown in Fig. 4. Consistent with the results in bottles, adding desulfurizers did not promote or restrict biogas or methane production in $5 \mathrm{~L}$ fermentation, although the $\mathrm{pH}$ values were slightly lower than the control, especially in the fermenter with $\mathrm{FeCl}_{3}$. In Fig. 3 (c), the pH decreased from 7.4 to 6.2 quickly in the first three or four days, corresponding the hydrolysis and acidogenesis stages with acid accumulated in anaerobic fermentation, and then it rose slowly to about
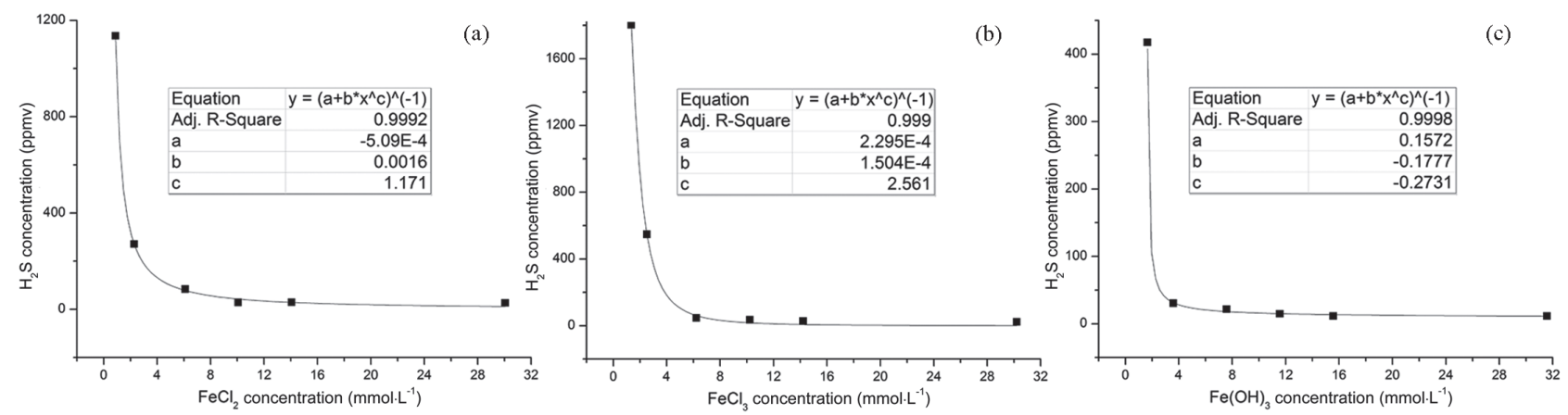

Fig. 2. Correlation curve and equation of desulfurizer concentration in liquid and $\mathrm{H}_{2} \mathrm{~S}$ concentration in biogas.

Table 2. Addition amounts of $\mathrm{FeCl}_{2}, \mathrm{FeCl}_{3}$, and $\mathrm{Fe}(\mathrm{OH})_{3}$ under different desulfurization requirements, and actual desulfurization efficiency.

\begin{tabular}{|c|c|c|c|c|c|c|}
\hline \multirow{2}{*}{$\begin{array}{c}\text { In-situ } \\
\text { desulfurizer }\end{array}$} & \multirow{2}{*}{$\begin{array}{c}\text { Required } \mathrm{H}_{2} \mathrm{~S} \\
\text { concentration (ppmv) }\end{array}$} & \multicolumn{3}{|c|}{ Dosage prediction } & \multicolumn{2}{|c|}{ Experiment results } \\
\hline & & $x(\mathrm{mmol} \mathrm{L}-1)$ & $m_{r}(\mathrm{mmol})$ & $m(\mathrm{mmol})$ & $\begin{array}{c}\text { Actual } \mathrm{H}_{2} \mathrm{~S} \\
\text { concentration (ppmv) }\end{array}$ & $\begin{array}{c}\text { Desulfurization rate } \\
(\%)\end{array}$ \\
\hline $\mathrm{FeCl}_{2}$ & $\leq 120$ & 4.31 & 2.50 & 17.59 & 163.0 & 92.6 \\
\hline $\mathrm{FeCl}_{3}$ & $\leq 200$ & 3.86 & 1.60 & 15.11 & 180.3 & 91.8 \\
\hline $\mathrm{Fe}(\mathrm{OH})_{3}$ & $\leq 100$ & 1.99 & 1.68 & 8.65 & 89.4 & 95.8 \\
\hline
\end{tabular}



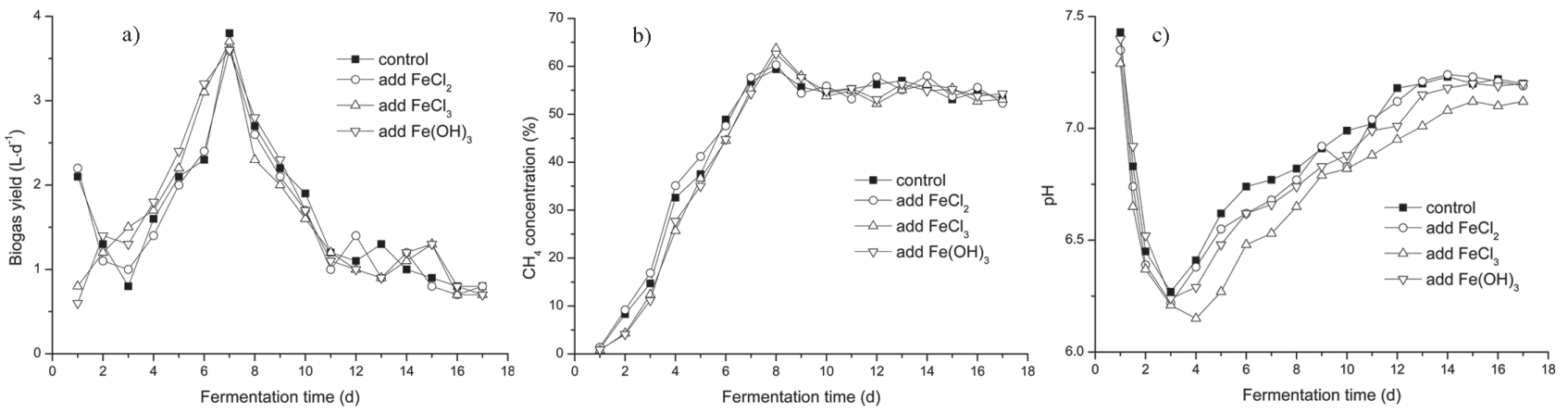

Fig. 3. Changes of biogas yields, $\mathrm{CH}_{4}$ concentrations, and $\mathrm{pH}$ when using $\mathrm{FeCl}_{2}, \mathrm{FeCl}_{3}$, and $\mathrm{Fe}(\mathrm{OH})_{3}$ as in-situ desulfurizers in $5 \mathrm{~L}$ fermenters. The control is no desulfurizer added.

7.2, demonstrating the subsequent methanogenesis stage. Fig. 4 indicates that the production of $\mathrm{H}_{2} \mathrm{~S}$ also mainly occurred during hydrolysis and acidogenesis stages, and the $\mathrm{H}_{2} \mathrm{~S}$ content of the control went up to 4918.4 ppmv on the fourth day of fermentation. In the fermenters adding in-situ desulfurizers, the peak contents of $\mathrm{H}_{2} \mathrm{~S}$ ranged from 200 to 600 ppmv. The average $\mathrm{H}_{2} \mathrm{~S}$ concentrations of $5 \mathrm{~L}$ fermentation are given in Table 2. When $\mathrm{FeCl}_{2}$ was used as desulfurizer, the actual $\mathrm{H}_{2} \mathrm{~S}$ concentration was 163.0 ppmv, which was worse than required (120 ppmv), but still relatively close. When $\mathrm{FeCl}_{3}$ and $\mathrm{Fe}(\mathrm{OH})_{3}$ were applied, the $\mathrm{H}_{2} \mathrm{~S}$ concentrations in biogas were 180.3 and 89.4 ppmv, respectively, which were close to the required desulfurization level (200 and $100 \mathrm{ppmv}$ ), and even a little better. From bottles to fermenters, the working volume increased by 140 times, and the prediction model showed good adaptability and effectiveness.

In the microscopic mechanism, a process of insitu desulfurization will include the competition and collaboration of microorganisms, reactions of sulfur and iron, etc. $[6,16]$. But for the prediction of desulfurizer dosage, this simple and practical method can be applied regardless of the complex principles. The calculated dosage should be adjusted flexibly based on the real

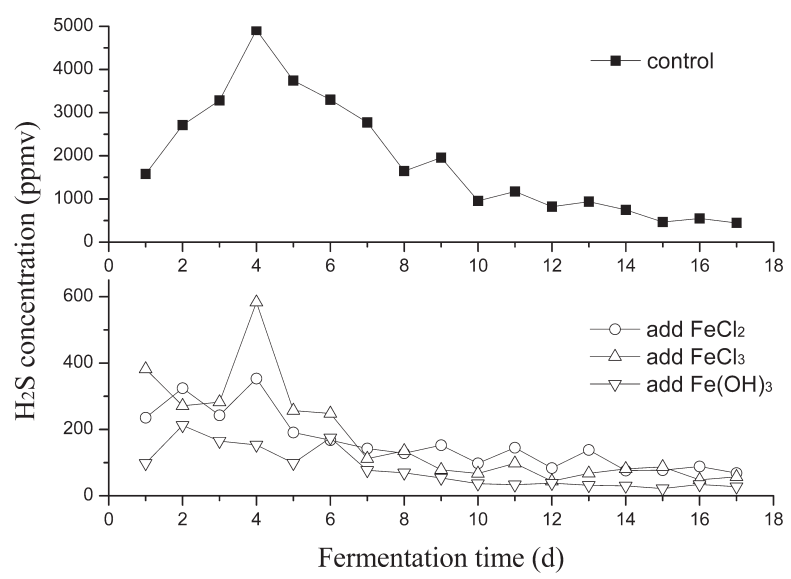

Fig. 4. Changes of $\mathrm{H}_{2} \mathrm{~S}$ concentrations when using $\mathrm{FeCl}_{2}, \mathrm{FeCl}_{3}$, and $\mathrm{Fe}(\mathrm{OH})_{3}$ as in-situ desulfurizers in $5 \mathrm{~L}$ fermenters. The control is no desulfurizer added. operation. And according to the actual situations, the experiments for dosage prediction can change the scale, reactor type, batch or continuous feed, etc.

In this study, two batches of CM were used, and the VS of CM2 was much lower than CM1 due to the high sand content. For the experiments of adding $\mathrm{FeCl}_{2}$ and $\mathrm{FeCl}_{3}, \mathrm{CM} 1$ was fed in bottles, while CM2 was fed in $5 \mathrm{~L}$ fermenters. But the prediction formulas calculated through bottle experiments were applied well in $5 \mathrm{~L}$ fermentation, indicating that the prediction models were not sensitive to the property fluctuation of CM. In a follow-up study, the influence of the substrate change to the prediction model should be evaluated in detail, and the adaptability of this method to other substrates also needs to be tested.

\section{Conclusion}

How to accurately determine the dosage of added desulfurizer is a key question to in-situ desulfurization. In this study, three iron compounds $\left(\mathrm{FeCl}_{2}, \mathrm{FeCl}_{3}\right.$ and $\mathrm{Fe}(\mathrm{OH})_{3}$ ) were selected as good-performing in-situ desulfurizers for CM fermentation, and used in the modeling experiments. For the establishment of the prediction model, regardless of the complex reactions, the dosage of desulfurizer was simply divided into two parts: one part for consumption of released $\mathrm{H}_{2} \mathrm{~S}$ and the other part for guaranteeing a certain desulfurizing level. With this idea, the prediction formulas were fitted and applied successfully in a $5 \mathrm{~L}$ fermentation system. To our knowledge, it is the first time that the prediction method for an in-situ desulfurizer dosage has been proposed. The method could be verified and improved through more experiments in laboratory, and practices in actual biogas plants.

\section{Acknowledgments}

This work was supported by the National Natural Science Foundation of China (21406263), and the Science Foundation of China University of Petroleum, Beijing (2462015YQ1303). 


\section{References}

1. RYCKEBOSCH E., DROUILLON M., VERVAEREN H. Techniques for transformation of biogas to biomethane. Biomass Bioenergy 35, 1633, 2011.

2. ANDERSSON F.A.T., KARLSSON A., SVENSSON B.H., EJLERTSSON J. Occurrence and abatement of volatile sulfur compounds during biogas production. J. Air Waste Manage. Assoc. 54, 855, 2004.

3. SCHIEDER D., QUICKER P., SCHNEIDER R., WINTER H., PRECHTL S., FAULSTICH M. Microbiological removal of hydrogen sulfide from biogas by means of a separate biofilter system: experience with technical operation. Water Sci. Technol. 48, 209, 2003.

4. WEITHÄUSER M., SCHOLWIN F., FISCHER E.R., GROPE J., WEIDELE T., GATTERMANN H. Gas processing and options for utilisation. In Guide to BiogasFrom production to use; Fachagentur Nachwachsende Rohstoffe e. V. (FNR): Gülzow, 115-140, 2010.

5. ABATZOGLOU N., BOIVIN S. A review of biogas purification processes. Biofuels, Bioprod. Biorefin. 3, 42, 2009.

6. ZHOU Q., JIANG X., LI X., JIANG W. The control of $\mathrm{H}_{2} \mathrm{~S}$ in biogas using iron ores as in situ desulfurizers during anaerobic digestion process. Appl. Microbiol. Biotechnol. 100, 8179, 2016.

7. ZHANG L., KELLER J., YUAN Z. Inhibition of sulfatereducing and methanogenic activities of anaerobic sewer biofilms by ferric iron dosing. Water Res. 43, 4123, 2009.

8. SUN J., PIKAAR L., SHARMA K.R., KELLER J., YUAN Z. Feasibility of sulfide control in sewers by reuse of iron rich drinking water treatment sludge. Water Res. 71, 150, 2015.
9. FIRER D., FRIEDLER E., LAHAV O. Control of sulfide in sewer systems by dosage of iron salts: comparison between theoretical and experimental results, and practical implications. Sci. Total Environ. 392, 145, 2008.

10. APHA. Solids. In Standard Methods for the Examination of Water and Wastewater, 20th ed; American Public Health Association: Washington, D.C., 2540, 1998.

11. FRIEHE J., WEILAND P., SCHATTAUER A. Fundamentals of anaerobic digestion. In Guide to Biogas-From production to use; Fachagentur Nachwachsende Rohstoffe e. V. (FNR): Gülzow, 21-31, 2010.

12. TAKASHIMA M., SPEECE R., PARKIN G.F. Mineral requirements for methane fermentation. Crit. Rev. Env. Sci. Tec. 19, 465, 1990 .

13. DEMIREL B., SCHERER P. Trace element requirements of agricultural biogas digesters during biological conversion of renewable biomass to methane. Biomass Bioenergy 35, 992, 2011.

14. CASALS E., BARRENA R., GARCÍA A., GONZÁLEZ E., DELGADO L., BUSQUETS-FITÉ M., FONT X., ARBIOL J., GLATZEL P., KVASHNINA K. Programmed iron oxide nanoparticles disintegration in anaerobic digesters boosts biogas production. Small 10, 2801, 2014.

15. JING Z., HU Y., NIU Q., LIU Y., LI Y.Y., WANG X.C. UASB performance and electron competition between methane-producing archaea and sulfate-reducing bacteria in treating sulfate-rich wastewater containing ethanol and acetate. Bioresour. Technol. 137, 349, 2013.

16. YANG S.L., TANG Y.Q., GOU M., JIANG X. Effect of sulfate addition on methane production and sulfate reduction in a mesophilic acetate-fed anaerobic reactor. Appl. Microbiol. Biotechnol. 99, 3269, 2015. 
